\title{
ПPИPOAHИЧO-ГEOГPACD/ЧII IOCNIOXEHHI
}

УДК $911.2 / 3+502.43$

\section{О. Г. Голубцов ${ }^{1}$, М. Г. Чорний \\ ЗАСТОСУВАННЯ ЛАНДШАФТНОГО ПЛАНУВАННЯ ДЛЯ СТВОРЕННЯ ПРОЕКТУ КАНІВСЬКОГО БІОСФЕРНОГО РЕЗЕРВАТУ}

\begin{abstract}
А. Г. ГолУбцов ${ }^{1}$, Н. Г. Черный
ПРИМЕНЕНИЕ ЛАНДШАФТНОГО ПЛАНИРОВАНИЯ ДЛЯ СОЗДАНИЯ ПРОЕКТА КАНЕВСКОГО БИОСФЕРНОГО PEЗEPBATA

1 Институт географрии Национальной академии наук Украины, Киев

2 Учебно-научный центр «Институт биологии» Киевского национального университета им. Тараса Шевченко В работе представлены результаты разработки Каневского биосферного резервата, полученные в рамках украинско-германского проекта «Ландшафтное планирование в Украине» (2010-2014). Для разработки впервые в Украине применены методические подходы ландшафтного планирования - ключевого инструмента планирования, направленного на сохранение природы и уход за ландшафтом. Основой работы являются многолетние исследования региона Среднего Приднепровья, проводимые на базе Каневского природного заповедника, и опыт создания системы заповедных территорий различных уровней охраны. Обработка и анализ данных о территории исследования осуществлен с использованием геоинформационных технологий. Применение ландшафтного планирования позволило сконфигурировать биосферный резерват таким образом, чтобы представить в его пределах все многообразие региона, а также предложить оптимальную схему функционального зонирования, основой которого являются результаты комплексной оценки компонентов природы.
\end{abstract}

Ключевые слова: ландшафрт; ландшафтное планирование; биосферный резерват; геоинформационные методы.

\section{O. Golubtsov', M. Chornyi ${ }^{2}$}

APPLICATION OF LANDSCAPE PLANNING FOR CREATION PROJECT KANIVSKY BIOSPHERE RESERVE

${ }^{1}$ Institute of Geography of the National Academy of Sciences of Ukraine, Kyiv

2 Institute of Biology, Taras Shevchenko National University of Kyiv

The paper presents the results of Kanev Biosphere Reserve development research received within the framework of UkrainianGerman project "Landscape Planning in Ukraine" (2010-2014). For this development the methodological approaches in landscape planning - a key planning tool aimed at preserving nature and landscape management, were the first time applied in Ukraine. The foundation of the study is extensive year by year research of the Middle Dnieper region, carried out at the Kanev Nature Reserve, and the experience of creating a system of protected areas with different levels of protection. Data processing and analysis about the studied area was conducted using GIS technologies. Application of landscape planning allowed to configure the biosphere reserve in such way, so that present within it the diversity of the whole region, as well as offer an optimal scheme of functional zoning, based on the results of a comprehensive nature components evaluation.

Keywords: landscape; landscape planning; Biosphere Reserve; GIS methods.

\section{Актуальність питання}

На шляху досягнення сталого розвитку важливим завданням $\epsilon$ збільшення площі природнозаповідних територій $з$ природними ландшафтами до рівня, достатнього для збереження їхнього різноманіття, властивого природного стану [1]. Разом 3 тим, створення в Україні нових природоохоронних територій вищих категорій охорони природних заповідників, біосферних заповідників - пов'язане зі значними труднощами правового та соціально-економічного характеру. Цілі збереження біо- та ландшафтного різноманіття часто конфліктують $з$ інтересами природокористування та економічного розвитку територій.

Показова ситуація в Центральній Україні [19] (рис 2.А ): тут на території, що становить 1/5 площі України, функціонує лише один природоохоронний об'єкт вищої категорії охорони - Канів- ський природний заповідник (площа - 2027 га), а також кілька новостворених національних природних парків. Підпорядкованість цих об'єктів різним відомствам призводить до неузгодженості дій і відсутності комплексного підходу до виконання природоохоронних цілей. Рішення проблеми вбачалося у створенні в регіоні біосферного заповідника на основі Канівського природного заповідника - природоохоронної та науково-дослідної установи, що успішно функціонує від 1923 року. Але неодноразові спроби створення природного заповідника натрапили на ряд юридичних, економічних і соціальних проблем [11 ].

Для запобігання подібних конфліктів між природоохоронними та економічними цілями робоча група програми “Людина і біосфера" ЮНЕСКО запропонувала Конщепиію біосферного резервату. Згідно з нею виділяються особливі території - біо- 
сферні резервати, у межах яких забезпечуються стійка рівновага між конфліктуючими цілями збереження біорізноманіття, сприяння економічному розвитку та збереження культурних цінностей [3, 20]. Враховуючи правові та соціально-економічні реалії України, найбільш ефективною альтернативою проекту біосферного заповідника може стати Канівський біосферний резерват.

M е т а цього дослідження - запропонувати проект біосферного резервату, який має відповідати принципам Севільської стратегії. Методологічною основою розробки є ландшафтне планування - просторове планування навколишнього середовища, спрямоване на вивчення мультифункціональності ландшафту, передумова якого - стале природокористування [18].

Робота здійснена в рамках науково-дослідного проекту «Ландшафтне планування в Україні» (2011-2014), який виконаний Інститутом географії НАН України на прикладі Черкаської області [9, 17] за експертною участю Технічного Університету Берліна (проф. Ш. Хайланд, А. Май) та Технічного Університету Дрездена (проф. К. Шмідт) та за сприяння Федерального відомства з охорони природи Німеччини (BfN).

\section{Об'скти та методи дослідження}

Згідно Севільської стратегії «біосферними резерватами» прийнято називати території суходільних i/або прибережних морських екосистем або їхні поєднання, які визнані міжнародною програмою ЮНЕСКО « Людина і Біосфера» [20]. Природоохоронні території, що претендують на статус біосферного резервату, повинні поєднувати реалізацію функцій збереження ландшафтів, розвитку соціально-економічної сфери та науково-технічної функції, спрямованої на підтримку досліджень та освіти. Обов'язковими є такі критерії:

- охоплення всього спектру репрезентативних екосистем;

- площа повинна бути достатньою з точки зору збереження біорізноманіття та поставлених завдань;

- функціональне зонування;

- наявність менеджмент-плану для управління територією.

Діяльність біосферних резерватів спрямована на те, щоб зробити їх показовими об'єктами для вивчення і демонстрації підходів до збереження середовища та сталого розвитку в регіоні.

Завдання розроблення проекту Канівського біосферного резервату i функціональне зонування резервату здійснюється на основі ландшафтного планування [18]. Йдеться про тривалу охорону: біорізноманіття; здатності природних екосистем до функціонування та саморегуляції; різноманітності, своєрідності і краси природи та ландшафту, а також значимості ландшафтів для відпочинку. Однак мова йде не тільки про охорону видів фауни і флори або образу ландшафту, так само мають охоронятися грунти, повітря, води, а також зберігатися можливості для тривалого збалансованого природокористування [15]. Об' єктом дослідження при цьому $\epsilon$ як природні, так і антропогенно змінені ландшафти [16].

Загальна схема робіт 3 розроблення проекту Канівського біосферного резервату, як частини ландшафтного планування, представлена на схемі (рис. 1). Інвентаризацію, систематизацію, аналіз та візуалізацію просторових даних виконано із застосуванням геоінформаційних методів, використано програмне забезпечення ArcGIS (ESRI).

\section{Виклад основного матеріалу}

Ідея створення біосферного резервату задекларована на початковому етапі робіт $з$ впровадження ландшафтного планування. За результатами попередніх консультацій виконавців, експертів і представників органів державної влади цю пропозицію затверджено як рамкову ціль проекту. 3 соціальноекономічної точки зору Черкаська область - депресивний регіон, який перебуває в пошуку нових напрямів для розвитку. Тому створення біосферного резервату - це ще й іміджевий проект, важливий для поліпшення інвестиційної привабливості області та зацікавленості туристів 3 інших областей України.

Конфігурація і зонування резервату. Один 3 важливих критеріїв створення біосферного резервату - наявність в його межах ландшафтів, репрезентативних для регіону. Для визначення меж Канівського біосферного резервату в ході реалізації інвентаризаційно-оцінювального етапу ландшафтного планування проведено детальні дослідження природних умов регіону. 3 усього масиву даних відібрано матеріали, які є найважливішими для обгрунтування контурів біосферного резервату. Це карти, які характеризують: поширення типів біотопів; розташування ареалів рідкісних видів флори i фауни; структуру грунтового покриву і наявність рідкісних грунтів; природні та сучасні ландшафти; ступінь антропогенного перетворення ландшафтів; структуру сучасного природокористування; мережу існуючих природно-заповідних територій.

ГІС- аналіз карт дав можливість визначити межі проектованого біосферного резервату таким чином, щоб у його межах було представлене все різноманіття регіону - ландшафти, збережені в природному (наближеному до природного) стані, ділянки 3 найбільшим рівнем біо- і ландшафтного різноманіття і антропогенні ландшафти різних типів, ареали поширення рідкісних видів рослин i тварин.

Функціональне зонування біосферних резерватів спрямоване на виділення в його межах ареалів, 


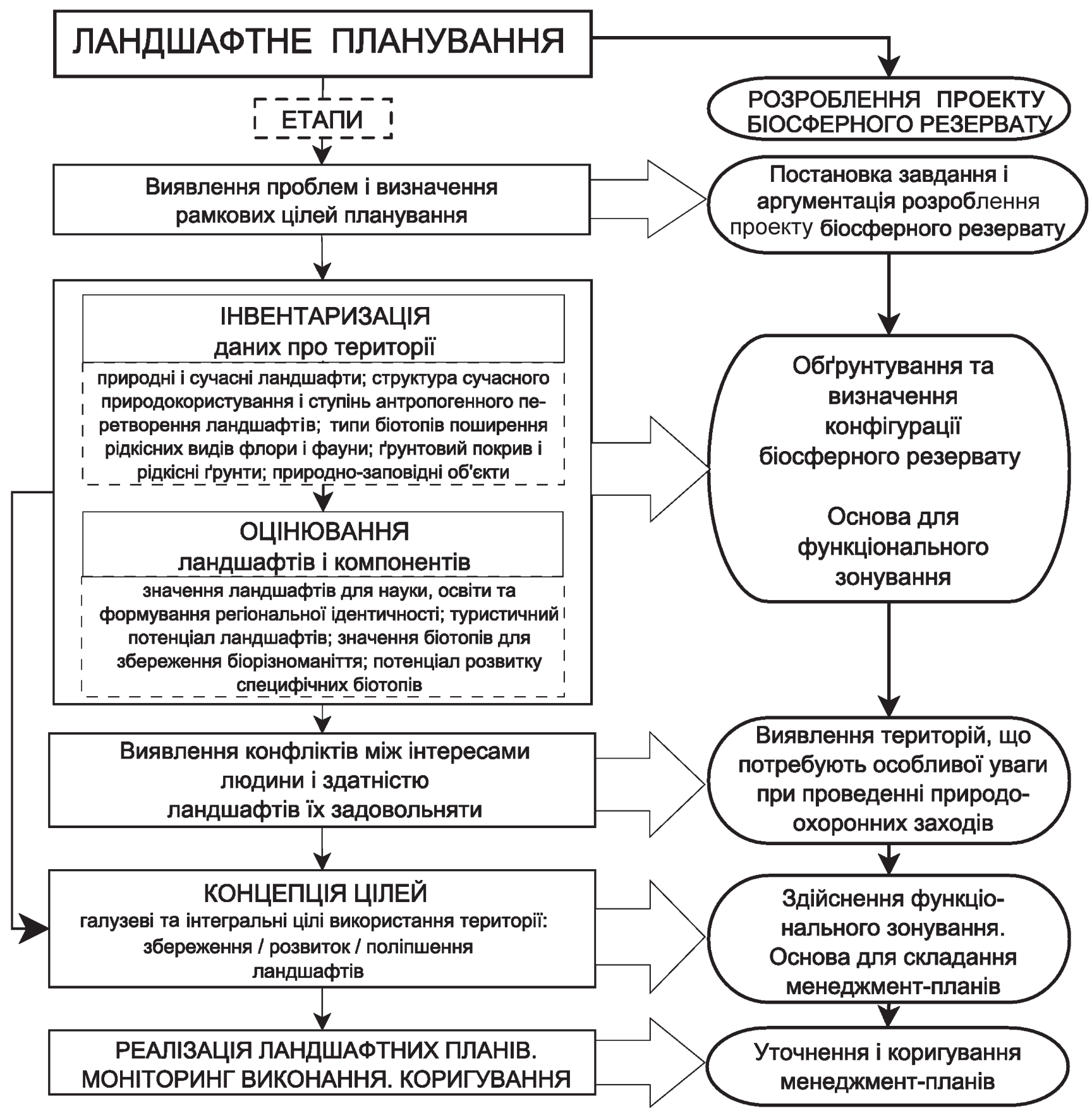

Рисунок 1. Схема розроблення проекту Канівського біосферного резервату на основі ландшафтного планування

актуальний стан яких найбільше відповідає завданням реалізації основних функцій - збереження ландшафтів, розвитку соціально-економічної сфери та науково-технічної функції, спрямованої на підтримку досліджень та освіти. У ландшафтному плануванні передбачається оцінка ландшафтів та їх компонентів у категоріях значення для виконання певної функції та чутливості до існуючих або можливих навантажень. На основі аналізу результатів такого оцінювання приймається рішення про подальші цілі їхнього використання.
Типи цілей - збереження та підтримка актуального стану ландшафтів, розвиток альтернативних видів їх використання, поліпшення стану ландшафтів, що зазнають негативних впливів [10, 18, 12]. Диференціацію території планування за типами цілей представлено на картах, які і є основою для функціонального зонування біосферного резервату.

До основних територій біосферного резервату доцільно віднести ландшафти, для яких рекомендовані цілі з б е р е ж е н н я природних місць існування типових видів рослин і тварин; місць 
поширення і концентрації рідкісних видів; високого ступеня ландшафтного різноманіття та унікальних ландшафтних комплексів [13].

Буферні зони, що оточують ядра резервату, мають пом'якшити перехід до заповідних територій, а також дають можливість проводити окремі активні заходи 3 підтримки та охорони біорізноманіття, залучати туристів. У проектованому резерваті ключовими ділянками буферних зон можуть бути численні природоохоронні об'єкти різного природоохоронного статусу: ландшафтні заказники (Тарасів Обрій, Максим), заказники різних видів разом із прилеглими територіями. Об'єднання їх у межах однієї функціональної зони дасть можливість розробити цілісну стратегію подальшого розвитку природоохоронної, наукової та рекреаційної діяльності.

До зони співробітництва доцільно включати ландшафти з високим значенням для різних сфер діяльності, а також ландшафти, що потребують особливого догляду і спеціальних заходів для підтримки або відновлення високого значення. Тут ландшафтне планування допомагає структурувати територію щодо найбільш оптимального землекористування у межах резервату.

Цілі розв и т у або поліпшен н я ландшафтів служать орієнтиром для розроблення спеціальних заходів 3 економічного і соціального розвитку, сталого в соціально-культурному та екологічному відношенні.

Концепція біосферних резерватів пропонує якіс-но нове рішення щодо використання теритрій, які включаються до зони співробітництва.

Головне завдання цієї зони, яка може становити до 80\% площі резервату, - демонстрація нових, дружніх до природного середовища підходів у природокористуванні, які сприяли б сталому розвитку території. Концепцією біосферних резерватів передбачено, що природокористування у межах цих зон не обмежується, однак підтримується і заохочується ініціатива впровадження заходів, спрямованих на досягнення природоохоронних цілей.

Наприклад, абсолютно заповідний режим для цінних високопродуктивних екосистем в заплаві Дніпра, які сформувалися внаслідок багатовікового антропогенного впливу, призведе до деградації цих ділянок і зникнення багатьох рідкісних видів і навіть ценозів. Але регульоване подальше використання (сінокосіння, помірне випасання) таких екосистем дасть можливість підтримувати високий рівень біорізноманіття, зберігаючи при цьому традиційні види господарювання. Також може бути розроблено ряд заходів підтримки збалансованого сільського господарства. Наприклад, перспективним є оптимізація структури агроугідь залежно від чутливості грунтів до водної та вітрової ерозії для підвищення привабливості продукції може бути створено спеціальний бренд [21].
Характеристика проектованого Канівського біосферного резервату. Проектований резерват розташований в Центральній Україні (Середнє Придніпров'я), у межах Канівського, Золотоніського та Черкаського районів Черкаської області (рис. 2.Б). Важлива передумова його створення саме тут - наявність природоохоронних територій, розташованих поблизу одна від одної. Головна серед них - Канівський природний заповідник, що має вищий в Україні природоохоронний статус i знаходиться на перетині двох екокоридорів - Дніпровського та Галицько-Слобожанського [7].

Площа проектованого резервату становить

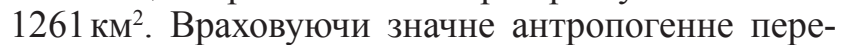
творення ландшафтів досліджуваного регіону, неможливо об'єднати ядра в один ареал. Проте Концепція біосферних резерватів допускає наявність декількох ядер, подібні резервати відносяться до типу кластерних. Тому пропонується виділити кілька ядер - основних територій, які оточені буферними зонами завширшки 2 - 3 кілометри. На заповідні ядра припадає 10\% території резервату, буферні зони - 29 \%, зони співробітництва - 61 \%.

Територія планованого Канівського біосферного резервату складається 3 трьох своєрідних за ландшафтною структурою ділянок (рис. 1 В), які доповнюють одна одну і охоплюють весь спектр екосистем Середнього Придніпров' я (детально $[6,11])$.

I. Канівська ділянка розташована на правому березі Дніпра у Канівському районі Черкаської області. Основний фактор високої значимості ділянки - унікальний, всесвітньовідомий геологогеоморфологічний об'єкт - Канівські дислокації, які простягаються на Правобережжі Канівського Придніпров'я смугою завдовжки 35 км і шириною 2-9 км між селами Трахтемирів, Ковалі, Колонча $[5,8]$. Дислокації являють собою складно деформовану товщу юрських, крейдових, палеогенових i антропогенових відкладів IV надзаплавної тераси Дніпра із системою дрібних складок-підкидів, лежачих, зрідка антиклінальних складок, діапірів. Потужність відкладів у дислокаціях становить 80100 м, подекуди 130 - 150 м. Походження Канівських дислокацій, на думку різних дослідників, могло бути пов'язане із зсувними чи тектонічними процесами, діяльністю дніпровського льодовика. Ландшафт, який сформувався на дислокаціях, вирізняється більшою, порівняно з навколишньою місцевістю, висотою (найвища точка - 255 м), глибоким і густим розчленуванням поверхні (внаслідок активних ерозійних процесів), через що це підвищення називають Канівськими горами.

Тут, на відносно невеликій території, сконцентровані практично всі типи ландшафтів, які характерні для Середнього Придніпров'я - лісостепові, широколистянолісові, лучні, болотні, що визначає високий рівень ландшафтного та біорізноманіття $[6,11]$ (рис. 2. Б: 1 - 4). 


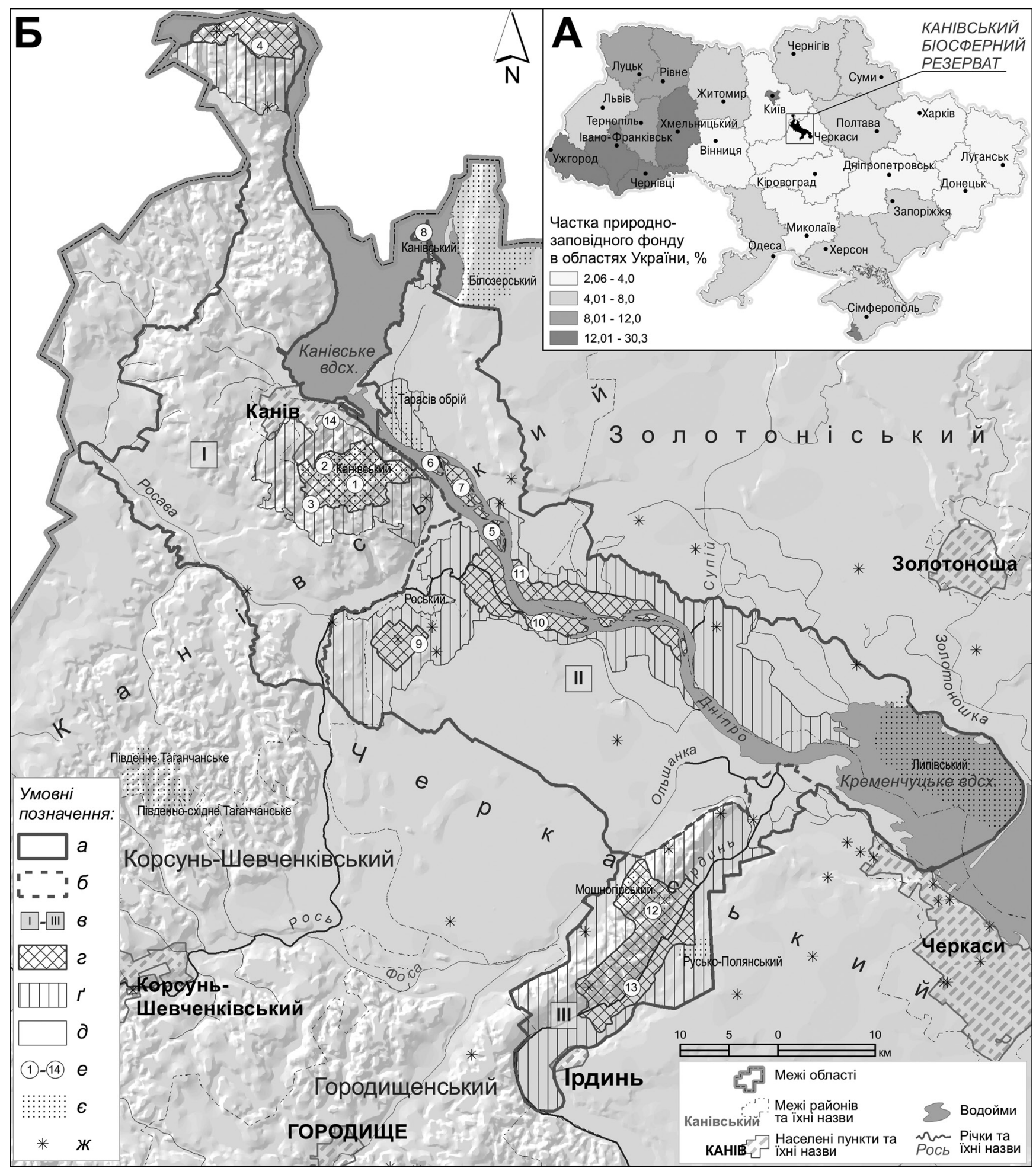

Рисунок 2. А - Частка площі природоохоронних територій в областях України, \%

Джерело даних: Звіт про виконання загальнодержавної програми формування наиіональної екологічної мережі України за 2011 рік. http://www.menr.gov.ua/content/article/6032

Б - Проект Канівського біосферного резервату

Умовні позначення до рис. 2. Б: $a$ - межі проектованого Канівського біосферного резервату; $\sigma$ - межі ділянок резервату; в - ділянки резервату: I - Канівська, II - Дніпровська, III - Ірдинсько-Мошногірська; г - основні території (ядра); $t$ - буферні зони; $\partial$ - зона співробітництва; $e$ - місцевості, особливо цінні для охорони природи 3 огляду на високий рівень ландшафтного та біорізноманіття: 1 - Канівський природний заповідник, 2 - урочище Вовчі Скоти, 3 - Канівсько-Яблунівська дача, 4 - Трахтемирівсько-Бучацький масив, 5 - острів Просеред, 6 - острів Круглик, 7 - острів Шелестів, 8 - Зміїні острови, 9 - урочище Перуна, 10 - гирло річки Рось, 11 - урочище Склярове, 12 - Мошногірський кряж, 13 - Ірдинські болота; місцевості високої культурної цінності: 14 - історичний центр м.Канева; існуючі об’єкти природно-заповідного фонду: $\epsilon$ - території об'єктів природно-заповідного фонду; їхні назви; ж - природні пам’ятки, заказники, заповідні урочища тощо. 
II. Дніпровська ділянка розташована в долині Дніпра, включно з островами і фрагментами ландшафтів борової тераси, - на лівобережжі в Канівському районі, в південно-західній частині Золотоніського району та в північній частині Черкаського району. Вона характеризується домінуванням лучно-болотних комплексів, цінність яких для охорони природи визначається надзвичайно високим рівнем біорізноманіття. Ландшафти долини Дніпpa $€$ середовищем існування численних видів рослин і тварин, внесених до Червоної книги України [11].

До основних територій резервату на Дніпровській ділянці слід віднести групу островів на Дніпpi та окремі масиви болотно-лісових угідь у заплаві Дніпра [6, 11] (рис. 2.Б: 5 - 11).

III. Ірдинсько-Мошногірська ділянка розташована в центральній частині Черкаського району, характеризується поєднанням болотних, мішано- i широколистяно-лісових ландшафтів. Ділянка неоднорідна у фізико-географічному відношенні: болотні ландшафти домінують у заплаві річки Ірдинь; на надзаплавній терасі розташований великий масив Черкаського бору. Лівий берег Ірдині високий, крутий, піднімається над рівнем Дніпра на 165 м і відомий під назвою Мошногірський кряж, що являє собою відроги Канівських дислокацій. Різноманітність природних умов визначає наявність дубово-соснових, широколистяних лісів, луків і низинних боліт [6, 11].

У межах Ірдинсько-Мошногірської ділянки до основних зон резервату доцільно включити асоціації широколистяних 90-100-річних лісів Мошногірського кряжу (рис. 2.Б: 12) і болота в заплаві p.ІІрдинь, представлені типовими евтрофними асоціаціями, які є унікальним місцем гніздування рідкісних видів птахів (рис. 2 .Б: 13).

Особливості культурних ландшафтів. Тривала історія освоєння регіону та особливості природокористування зумовили формування на території, що включається в біосферний резерват, своєрідних культурних ландшафтів. Їхньою найбільш виразною рисою є велика кількість археологічних та історичних пам'яток, які свідчать про багату на події історію регіону [4].

Поблизу Канева, на Тарасовій горі, знаходиться Шевченківський національний заповідник - важливий елемент культурного ландшафту області, значимий для формування не тільки регіональної, а й всеукраїнської ідентичності.
Особливе місце в проектованому біосферному резерваті займає місто Канів (перша документальна згадка - 1144 рік) з привабливим архітектурним, культурно-історичним ансамблем (на рис. 2 позначений індексом 14). У рамках резервату можуть бути розроблені заходи щодо збереження як окремих пам'яток, так і підтримки цілісного культурного ландшафту в старій частині міста. Також можуть отримати вагоміше обгрунтування ініціативи з розвитку та підтримки туризму та рекреації в місті Каневі та на його околицях.

\section{Висновки}

Проект Канівського біосферного резервату є результатом комплексних досліджень регіону Середнього Придніпров'я. Для його розроблення вперше в Україні застосовано методологічні підходи ландшафтного планування 3 широким використанням ГІС-технологій. У проекті враховано напрацювання попередніх ініціатив щодо створення природоохоронної території високого статусу на основі Канівського природного заповідника.

Гнучкість підходів до організації біосферних резерватів у поєднанні з ландшафтним плануванням дає можливість оптимально розподілити площу функціональних зон резервату, забезпечивши тим самим виконання природоохоронних функцій.

Матеріали ландшафтного планування в Черкаській області представляють загальну концепцію цілей і заходів з підтримки сталого розвитку в межах біосферного резервату. Для розроблення менеджмент-плану Канівського біосферного резервату необхідно виконати детальніші (масштаб 1:25000 ) роботи $з$ ландшафтного планування безпосередньо для його території.

Наявність та функціонування Канівського біосферного резервату (у разі його створення) сприятиме сталому розвитку всього регіону і формуванню екологічної свідомості населення, істотному посиленню взаємодії органів державного управління, ділових кіл та громадянського суспільства для реалізації природоохоронних цілей. Впровадження проекту важливе для оптимізації управлінської структури і вироблення спільної програми управління природоохоронною територією та уніфікації планів наукових досліджень. При цьому місцеве населення отримає нові можливості та іміджеві переваги для розвитку і підтримки господарської діяльності, насамперед у галузі туризму та рекреації, сільському господарстві.

\section{Лimepamypa:}

1. Закон України „Про загальнодержавну програму формування екологічної мережі України на 2000 -2015 роки”. - $2000 .-47$ с.

2. К Крижова Н. О. Атлас «Шляхами Великого Кобзаря». - Київ.: ДНВП «Картографія», 2013. - 88 с: іл.

3. Мадридский план действий для биосферных заповедников (2008-2013). UNESCO. - Мадрид, 2008. - 45 с. [Електронний pecypc]. - Режим доступу: http://unesdoc.unesco. org/images/0016/001633/ 163301r.pdf

4. Олійник Я. Б., Стеиюк В. В. Природні та етнокультурні феномени України [ монографія] // Видавництво: Київський університет. - Київ, 2008. - 216 с. 
5. Палієнко Е.Т., Мороз С.А., Куделя Ю.А. Рельєф та геологічна будова Канівського Придніпров’я. - Київ, 1971. - 96 с.

6. Перспективи розширення Канівського природного заповідника / М.Г.Чорний, В.М. Грищенко, В.Л. Шевчик та ін. // Заповідна справа в Україні. - 2011. - 17(1-2). - С. 103 - 101.

7. «Про Генеральну схему планування території України». Закон України від 7 лютого 2002 р. № 3059-ІІІ // Відомості Верховної Ради України. - 2002. - № 30. - Ст. 204.

8. Різниченко В. Природа Канівських дислокацій // Вісник Українського відділу Геологічного комітету. - Вип. 4, 1924.

9. Руденко Л. Г., Маруняк Е. А., Май А. Рамочные условия и организация работ по внедрению ландшафтного планирования в Украине // Актуальные проблемы ландшафтного планирования: Материалы Всеросс. научн.-практ. конф. - Москва: Изд-во МГУ, 2011. - С. 81-86.

10. Руководство по ландшафтному планированию. - Москва.: Гос. центр экол. программ. - Т. І. Принципы ландшафтного планирования и концепция его развития в России. - 2000. - 136 с.; Т. II. Методические рекомендации по ландшафтному планированию. - 2001. - $73 \mathrm{c.}$

11. Чорний М.Г., Чорна Л.О. Канівський природний заповідник: передумови створення, ретроспективний аналіз діяльності, сучасний стан та перспективи розвитку: монографія. - Київ: Видавничо-поліграфічний центр «Київський університет», 2013. $-384 \mathrm{c}$.

12. Auhagen, A. Landschaftsplanung in der Praxis / Stuttgart: Ulmer, 2002. - $416 \mathrm{~S}$.

13. Biosphärenreservat Rhön: Rahmenkonzept für Schutz, Pflege und Entwicklung / Bearb.: Planungsbüro Grebe, Landschafts- und Ortsplanung, Nürnberg. Auftraggeber: Bayerisches Staatsministerium für Landesentwicklung und Umweltfragen, München. Radebeul: Neumann, 1995.

14. European Landscape Convention. Florence, 20.X.2000. [Електронний ресурс] Сайт “Соuncil of Europe”. - Режим доступу: http:// conventions.coe.int/Treaty/EN/Treaties/Html/176.htm

15. Heiland, S. (2010): Landschaftsplanung. In: Henckel, D. et al. (Hrsg.): Planen - Bauen - Umwelt. Ein Handbuch. Wiesbaden. S. 294-300.

16. ILN (Institut für Landschaftspflege und Naturschutz der Universität Hannover) (1998): Definitionen aus dem Bereich von Landschaftspflege und Naturschutz. Manuskript, unveröff.

17. Landscape planning in Ukraine: the first landscape program. / L. Rudenko, A. Golubtsov,S.Lisovskyi et al. // Geography, Environment, Sustainability, 2013, vol. 06, No 04, p. 91-102.

18. Landschaftsplanung / [mit Beitr. von: Claus Bittner ]. Christina von Haaren (Hrsg.). - Stuttgart: UTB, Ulmer, $2004 .-527$ S.

19. Millennium Development Goals.Ukraine - 2013. National Report / Ministry of Economic Development and Trade of Ukraine. - Kyiv. 2013, $168 \mathrm{P}$.

20. The Statutory framework of the world network of biosphere reserves [Електронний ресурс] / MAB UNESCO. - Seville, 1995. // UNESCO. - Режим доступу: http://unesdoc.unesco.org/images/0010/001038/103849Eb.pdf

21. Ziele des UNESCO Biosphären reservates Spreewald [Електронний ресурс] // Сайт "Вiosphärenreservat Spreewald". Режим доступу: http://www.spreewald.de/spreewald/unesco-biosphaerenreservat/ziele-des-unesco-biosphaerenreservates-spreewald.html

\section{References}

1. The Law of Ukraine "On State Program of forming ecological network in Ukraine in 2000 -2015 years" (2000). (From Ukr.).

2. Kryzhova N.O. (2013). Atlas "Following the paths of the great Kobzar". Kyiv.: DNVP "Cartographia”. (From Ukr.).

3. Madrid plan of action for biosphere reserves (2008-2013). UNESCO (2008). Madrid. http://unesdoc.unesco.org/ images/0016/001633 / 163301r.pdf (From Rus.)

4. Oliynik Ya.B., Stetsyuk V.V. (2008). Ukraine Natural and ethno-cultural phenomena . Kyiv: Publisher: Kyiv University. (From Ukr.).

5. Palienko E.T., Moroz S.A., Kudelia Yu.A. (1971). Kaniv Pridneprovya's relief and geological structure. Kyiv. (From Ukr.).

6. Kaniv Nature Reserve enlargement prospects . M.H.Chornyy, V.M. Gryshchenko, V.L. Shevchyk et al.(2011). Reserve business in Ukraine, 17 (1-2), 101 - 103. (From Ukr.).

7. "On the General Scheme of landscape planning in Ukraine" (2002). Ukraine Law of 7 February, 2002yr. № 3059-III Bulletin of the Supreme Council of Ukraine,30. Article 204. (From Ukr.).

8. Riznychenko B. (1924). Nature of Kaniv dislocations. Bulletin of the Ukrainian Department of the Geological Committee. Vol. 4. (From Ukr.).

9. Rudenko L.G., Marunyak Ye.A., Mai A. (2011). Framework conditions and organization of work for the implementation of landscape planning in Ukraine. Current problems of landscape planning: materials of the Russia Statewide scientific applied conference. Moscow: Moscow State University Press edition, 81-86. (From Rus.)

10. Guidelines on landscape planning. Moscow: State Ecological programs Center. Vol. I: Principles of Landscape Planning and the concept of its development in Russia. (2000). Vol. II: Methodological guidelines for landscape planning. (2001). (From Rus).

11. Chornyy M.G., Chorna L.O. (2013). Kaniv Nature Reserve: background of creation, retrospective analysis of activities, current state and prospects of development. Kyiv: publishing center "Kyiv University". (From Ukr.).

12. Auhagen, A. (2002). Planning of edge in practice. Stuttgart: Ulmer. (From Germ.).

13. Biosphärenreservat Rhön: Scope compendium for defence, care and development. (1995). Bearb.: Planning bureau Grebe, Landschaftsand planning of place, Nuremberg. Auftrag bearer: Bavarian ministry of the state for waterside development and questions of environment. Munich. Radebeul: New man. (From Germ.).

14. European Landscape Convention (2000). Florence, 20.X.2000. Site "Council of Europe": http://conventions.coe.int/Treaty/EN/ Treaties/Html/176.htm

15. Heiland, S. (2010). Planning of edge. In: Henckel, D. et al. (Hrsg.): Plan, structures, environment. Wiesbaden, 294-300. (From Germ.).

16. ILN (Institute for the care of edge and conservancy university of Hannover)) (1998): Decisions from the area of care of edge and conservancy. Manuscript. (From Germ.).

17. Landscape planning in Ukraine: the first landscape program (2013). L. Rudenko, A. Golubtsov, S.Lisovsky et al. Geography, Environment, Sustainability, vol. 06, 04, 91-102. 
18. Landschaftsplanung [mit Beitr. von: Claus Bittner] (2004). Christina von Haaren (Hrsg.). Stuttgart: UTB, Ulmer.

19. Millennium Development Goals. Ukraine 2013 (2013). National Report. Ministry of Economic Development and Trade of Ukraine. Kyiv.

20. The Statutory framework of the world network of biosphere reserves (1995). MAB UNESCO. Seville. UNESCO. http://unesdoc. unesco.org/images/0010/001038/103849Eb.pdf

21. Ziele des UNESCO Biospheren reservates Spreewald. Site "Biospherenreservat Spreewald": http://www.spreewald.de/spreewald/ unesco-biosphaerenreservat/ziele-des-unesco-biosphaerenreservates-spreewald.html

${ }^{1}$ Інститут географії Національної академії наук України, Київ

2 Учбово-науковий центр «Інститут біології»

Київського національного університету імені Тараса Шевченка

Стаття надійшла до редакції 13.05.2014

УДК 556.512(477)

Л.О. Горбачова

ПРОСТОРОВИЙ РОЗПОДІЛ ЗВ'ЯЗКІВ МІЖ ЕЛЕМЕНТАМИ ВОДНОГО БАЛАНСУ РІЧКОВИХ ВОДОЗБОРІВ УКРАЇНИ

\section{Л.А. Горбачёва \\ ПРОСТРАНСТВЕННОЕ РАСПРЕДЕЛЕНИЕ СВЯЗЕЙ МЕЖДУ ЭЛЕМЕНТАМИ ВОДНОГО БАЛАНСА РЕЧНЫХВОДОСБОРОВ УКРАИНЫ}

Украинский гидрометеорологический институт Государственной службы Украины по чрезвычайным ситуациям и Национальной академии наук Украины, Киев

Рассчитаны значения элементов водного баланса водосборов рек, расположенных в разных физико-географических зонах Украины, за период 1961-2010 гг. Определены типы связей по линейным корреляционным связям между осадками, испарением и водным стоком для водосборов рек и исследовано их пространственное распределение.

Ключевые слова: водосбор; осадки; испарение; среднегодовой сток; метод водного баланса.

\section{Gorbachova}

SPATIAL LINKS DISTRIBUTION BETWEEN WATER BALANCE ELEMENTS OF THE UKRAINE RIVER CATCHMENTS

Ukrainian Hydrometeorological Institute of State Service of Emergencies of Ukraine and of National Academy of Sciences of Ukraine, Kyiv

The values of water balance elements of the rivers catchments located in different Ukraine physiographic zones have been calculated for the period 1961-2010 years. The types of the linear correlation between precipitation, evaporation and runoff of the rivers for the catchments has been determined and their spatial distribution has been researched.

Key words: catchment; rainfall; evaporation; average annual runoff; water balance method.

\section{Постановка проблеми та аналіз останніх} досліджень і публікацій

Розробленню методик та методів визначення елементів водного балансу присвячена велика кількість публікацій. Починаючи 3 другої половини XX ст. метод водного балансу є майже основним для оцінювання впливу кліматичних змін на водний стік як окремих річкових басейнів, так і регіонів, країн та континентів [7]. Найбільш поширені дослідження стосовно складання водних балансів будь-яких територій (від малих річкових басейнів до континентів) та за різні проміжки часу (місяць, сезон, рік, багаторічний період) $[2,4,5,8]$. Останні грунтовні дослідження складових водного балансу річкових басейнів на території України виконано в середині 80-х років минулого століття [8]. Разом 3 тим, актуальним завданням $є$ дослідження взаємозв'язків між елементами водного балансу річкових водозборів, розташованих у різних фізико-гео- графічних зонах [2]. Такі дослідження дозволяють виявити зональні 'та азональні закономірності елементів водного балансу і проаналізувати їхній часовий та просторовий розподіл. На жаль, в Україні останнім часом цьому напрямку досліджень не приділяється належна увага.

М е т о ю цієї публікації $є$ дослідження за багаторічний період просторового розподілу взаємозв'язків основних елементів водного балансу річкових водозборів, розташованих у різних фізико-географічних зонах України.

\section{Виклад основного матеріалу}

Умови формування річкового стоку на території України є дуже різноманітними, що зумовлюється iii фізико-географічними особливостями. Водозбори річок України розташовані в зонах підвищеної, достатньої та недостатньої водності [3]. Саме тому для дослідження було взято 76 водозборів, які добре 